\title{
The relationship between vitamin $D$ deficiency and non-cardiac chest pain in children aged 9-17 years
}

\author{
Ali Kanık1, Tülay Demircan², Barış Güven², Yavuz Demirçelik², *Kayı Eliaçık ${ }^{2}$ İnanç Karakoyun², Cem \\ Karadeniz $^{1}$, Mehmet Helvacı ${ }^{2}$
}

Sri Lanka Journal of Child Health, 2022; 51(1): 58-61

DOI: http://dx.doi.org/10.4038/sljch.v51i1.9994

\begin{abstract}
Introduction: Chest pain in children is rarely associated with a cardiac cause. Musculoskeletal system-related pain is one of the main reasons for chest pain in children. Vitamin D deficiency in children might cause severe symptoms in the skeletal system.
\end{abstract}

Objectives: To determine the relationship between vitamin $\mathrm{D}$ deficiency and non-cardiac chest pain among children aged 9-17 years.

Method: In this cross-sectional study, we assessed 92 children with non-cardiac chest pain (NCCP) and a control group of 94 children who presented to the cardiology outpatient clinics of Tepecik Teaching and Research Hospital, İzmir, Turkey, between 1 December 2019 and 31 March 2020. The serum 25-hydroxyvitamin D levels were measured and compared between these groups.

Results: The median (interquartile range) vitamin $D$ levels in patients with non-cardiac chest pain and healthy controls were 12.78 (7.28) and 12.27 (9.02) $\mathrm{ng} / \mathrm{mL}$ respectively. Vitamin D levels were similar in both groups $(\mathrm{p}=0.625)$.

Conclusions: This study did not show any association between vitamin D deficiency or suboptimal vitamin D levels and non-cardiac chest pain in children aged 9-17 years.

(Key words: 25-hydroxyvitamin D, Non-cardiac chest pain, Children, Winter)

$\overline{1} \overline{\text { Izmir Katip Celebi University, School of Medicine, }}$ Turkey, ${ }^{2}$ Izmir Tepecik Teaching Hospital, Turkey

*Correspondence: kayieliacik@gmail.com

iD https//orcid.org/ 0000-0001-9529-9719

(Received on 11 February 2021: Accepted after revision on 19 March 2021)

The authors declare that there are no conflicts of interest

Personal funding was used for the project.

Open Access Article published under the Creative

Commons Attribution CC-BY (c) (i) License

\section{Introduction}

Chest pain is common in children and adolescents resulting in numerous hospital admissions and a considerable amount of testing ${ }^{1,2}$. In contrast to adults, chest pain is rarely associated with a cardiac cause in children and adolescents ${ }^{3}$. An underlying organic cause for chest pain has been found in $2-$ $5 \%$ of cases admitted to paediatric wards and $3-7 \%$ of cases referred to cardiology clinics ${ }^{4}$. An underlying organic cause is unlikely, in the absence of positive findings on physical examination and chest pain during exercise. Although musculoskeletal and psychological disorders are common, they are frequently overlooked as possible causes of non-cardiac chest pain $(\mathrm{NCCP})^{5,6}$. Recent data from adult studies have shown that persistent non-specific musculoskeletal pain is associated with severe hypovitaminosis $\mathrm{D}^{7-9}$. However, data regarding the role of vitamin D deficiency in children with chest pain are scarce.

\section{Objectives}

To determine the relationship between vitamin D deficiency and non-cardiac chest pain among children aged 9-17 years.

\section{Method}

A total of 104 children aged 9-17 years who were consecutively referred to the cardiology outpatient clinics of Tepecik Teaching and Research Hospital, Izmir, Turkey, between 1 December 2019 and 31 March 2020 and diagnosed with NCCP were included in the study. Children with chronic disease (gastroesophageal reflux disease, cardiovascular disease, pulmonary disease, etc.) and non-native Turkish speakers were excluded from the study. In the current study, we also excluded those who had vitamin $\mathrm{D}$ supplementation or any medication that might influence their vitamin D level for at least six months before the evaluation. The remaining 92 patients with NCCP were included in the study. A total of 94 age-and sex-matched healthy children who were referred to the paediatric cardiology outpatient clinics for pre-participation of sport for cardiovascular screening were recruited as the control group. In Turkey, adolescents need a cardiovascular screening including physical and echocardiographic examination before joining the sports club. During this routine evaluation, they were asked to participate in the control group. 
A blood sample was collected from each participant into a clot-activating tube containing a gel separator (Ref No: 367955; BD Vacutainer ${ }^{\circledR}$ SST II Advance tube, $5 \mathrm{~mL}, 13$ x $100 \mathrm{~mm}$, NJ, USA). The tubes were kept upright at room temperature for a minimum of 30 minutes to allow complete blood clotting, then centrifuged for 10 min at $1500 \times$ g. Serum $25(\mathrm{OH}) \mathrm{D}$ measurements were performed using a chemiluminescence immunoassay on an Advia Centaur XP analyzer (Siemens Healthiness, Erlangen, Germany). The intra-assay and inter-assay coefficients of variation $(\mathrm{CV})$ for the $25(\mathrm{OH}) \mathrm{D}$ test were below $8 \%$ and $12 \%$, respectively. $25(\mathrm{OH}) \mathrm{D}$ concentrations over $20 \mathrm{ng} / \mathrm{ml}$ were considered as normal, concentrations below $12 \mathrm{ng} / \mathrm{ml}$ were classified as vitamin D deficiency and concentrations between $12 \mathrm{ng} / \mathrm{ml}$ and $20 \mathrm{ng} / \mathrm{ml}$ as a vitamin D insufficiency ${ }^{10}$.

A sample size calculation based on a one-tailed hypothesis, power of 0.90 and alpha of 0.05 predicted a sample size of 70 subjects per group was necessary.
Ethical issues: Ethical clearance for the study protocol was obtained from the Institutional Ethics Committee of İzmir Tepecik Teaching Hospital, Turkey (Ref. No. 09.10.2019/03). Informed written consent was obtained from the parents of the study participants.

Statistical analysis: All data were analysed using IBM SPSS Statistics v25 (IBM Corp., Armonk, New York, ABD). Categorical variables were presented as number and percentages and continuous variables as mean \pm standard deviations or medians with interquartile ranges. The student ttest was used for normally distributed data, MannWhitney $U$ test was used for non-normally distributed data. The Chi-Square test was used for categorical variables.

\section{Results}

There were 92 children (50 girls, 42 boys) in the study group and 94 in the control group (41 boys, 53 girls) aged 9-17 (mean age $13.13 \pm 2.58$ years). During the study period, there was no significant differences regarding the investigation time of the vitamin D levels in the 2 groups (Table 1).

Table 1: Vitamin D levels in both groups regarding the investigation time

\begin{tabular}{|c|c|c|c|}
\hline Characteristic & $\begin{array}{c}\text { Non-cardiac chest pain group } \\
(\boldsymbol{n = 9 2 )}\end{array}$ & $\begin{array}{c}\text { Control group } \\
(\boldsymbol{n}=\mathbf{9 4})\end{array}$ & p-value \\
\hline Time of investigation & 28 & 27 & \\
December & 16 & 23 & $0.130^{*}$ \\
January & 31 & 19 & \\
February & 17 & 25 & \\
March & $12.78(7.28)$ & $12.27(9.02)$ & $0.625^{\alpha}$ \\
\hline
\end{tabular}

*Chi-square test ${ }^{\alpha}$ Mann-Whitney U test

Table 2 shows the distribution of the vitamin D levels according to the cut-off value. In the study group $89 \%$ of the subjects had suboptimal levels of vitamin D compared to $87 \%$ in the control group. In both the study group and the control group $48 \%$ of subjects had vitamin D deficiency.

Table 2: Distribution of the vitamin D levels according to cut off value

\begin{tabular}{|l|c|c|c|}
\hline \multicolumn{1}{|c|}{ Vitamin D level } & $\begin{array}{c}\text { Non-cardiac chest pain group } \\
(\boldsymbol{n}=\mathbf{9 2})\end{array}$ & $\begin{array}{c}\text { Control group } \\
(\boldsymbol{n}=\mathbf{9 4})\end{array}$ & \multirow{2}{*}{ p-value* $^{*}$} \\
\hline$<12 \mathrm{ng} / \mathrm{mL}-\mathrm{n}(\%)$ & $44(48.0)$ & $45(48.0)$ & \multirow{2}{*}{0.995} \\
\hline $12-20 \mathrm{ng} / \mathrm{mL}-\mathrm{n}(\%)$ & $38(41.0)$ & $37(39.0)$ & \\
\hline $20-100 \mathrm{ng} / \mathrm{mL}-\mathrm{n}(\%)$ & $10(11.0)$ & $12(13.0)$ & \\
\hline
\end{tabular}

\section{*Chi-square test}

\section{Discussion}

This study assessed the relationship between the levels of vitamin D and non-cardiac chest pain. However, the findings did not show any relationship between vitamin $\mathrm{D}$ levels and noncardiac chest pain, there being equal numbers of children with vitamin D deficiency in both study and control groups. Chest pain is a problem that causes anxiety in both children and their parents ${ }^{11}$. A frequent cause for chest pain is joint and muscle dysfunction due to musculoskeletal disorders, such as costochondritis, stress fractures, Tietze's syndrome, and slipping rib syndrome ${ }^{5,12}$.

Vitamin D deficiency might cause severe symptoms in the skeletal system. Osteopenia can cause musculoskeletal pain including the rib region, associated with very low vitamin D levels ${ }^{13}$. Şanlı C, et $a l^{14}$ showed that bone mineral density and osteocalcin levels were found to be significantly low only in children with musculoskeletal-related chest pain. They concluded 
that bone turnover is a cause of chest pain in these children. This should lead clinicians to consider the musculoskeletal system as a common cause of chest pain without a clear mechanism ${ }^{15,16}$. It has been shown that low vitamin D status adversely affects bone health parameters in adolescents ${ }^{17}$. Vitamin D deficiency/insufficiency is common among adolescents in Turkey ${ }^{18,19}$. In the current study, suboptimal levels of vitamin D were found in more than $85 \%$ of children $9-17$ years of age. A possible explanation for this may be that all subjects in this study were recruited during the winter season. The lack of outside activity during winter time may be the reason for the low vitamin D levels.

\section{Conclusions}

This study did not show any association between vitamin D deficiency or suboptimal vitamin D levels and non-cardiac chest pain in children aged 9-17 years.

\section{References}

1. Brenner JI, Ringel RE, Berman MA. Cardiologic perspectives of chest pain in childhood: a referral problem? To whom? Pediatric Clinics of North America 1984; 31:1241-58.

https://doi.org/10.1016/S00313955(16)347 $19-8$

2. Fyfe DA, Moodie DS. Chest pain in paediatric patients presenting to a cardiac clinic. Clinical Pediatrics (Phila) 1984; 23: $321-4$.

https://doi.org/10.1177/000992288402300 603

PMid: 6723174

3. Roll M, Rosenqvist $M$, Sjöborg B. Unexplained acute chest pain in young adults: Disease patterns and medication use 25 years later. Psychosomatic Medicine 2015; 7: 567-74.

https://doi.org/10.1097/PSY.00000000000 00188

PMid: 25984822

4. Thull-Freedman J. Evaluation of chest pain in the paediatric patient. Medical Clinics of North America 2010; 94: 32747.

https://doi.org/10.1016/j.mcna.2010.01.00 4

PMid: 20380959

5. Jensen, S. Musculoskeletal causes of chest pain. Australian Family Physician 2001; 30: 834-9.
6. Eliacik K, Kanik A, Bolat $\mathrm{N}$, et al. Anxiety, depression, suicidal ideation, and stressful life events in non-cardiac adolescent chest pain: a comparative study about the hidden part of the iceberg. Cardiology in the Young 2017; 27: 1098103.

https://doi.org/10.1017/S10479511160021 09

PMid: 27830640

7. Wu Z, Malihi Z, Stewart AW, et al. The association between vitamin $D$ concentration and pain: a systematic review and meta-analysis. Public Health Nutrition 2018; 21: 2022-37. https://doi.org/10.1017/S13689800180005 51 PMid: 29559013

8. Wintermeyer E, Ihle C, Ehnert S, et al. Crucial role of vitamin $\mathrm{D}$ in the musculoskeletal system. Nutrients 2016; 1(8): 319.

https://doi.org/10.3390/nu8060319

PMid: 27258303 PMCid: PMC4924160

9. Gaikwad M, Vanlint S, Mittinity M, et al. Does vitamin D supplementation alleviate chronic nonspecific musculoskeletal pain? A systematic review and meta-analysis. Clinical Rheumatology 2017; 36(5): 12018. https://doi.org/10.1007/s10067-016-32051

PMid: 26861032

10. Munns CF, Shaw N, Kiely $\mathrm{M}$, et al. Global consensus recommendations on prevention and management of nutritional rickets. Journal of Clinical Endocrinology and Metabolism 2016; 101(2): 394-415. https://doi.org/10.1210/jc.2015-2175 PMid: 26745253 PMCid: PMC4880117

11. Tunaoglu FS, Olgunturk R, Akcabay S, et al. Chest pain in children referred to a cardiology clinic. Pediatric Cardiology 1995; 16: 69-72. https://doi.org/10.1007/BF00796820 PMid: 7784237

12. Gokhale J, Selbst SM. Chest pain and chest wall deformity. Pediatric Clinics of North America 2009; 56: 49-65. https://doi.org/10.1016/j.pcl.2008.10.001 PMid: 19135581

13. Heidari B, Shirvani JS, Firouzjahi A, et al. Association between nonspecific skeletal 
pain and vitamin D deficiency. International Journal of Rheumatic Diseases 2010; 13: 340-6.

https://doi.org/10.1111/j.1756185X.2010.0

1561.x

PMid: 21199469

14. Sanli C, Akalin N, Kocak U, et al. Could lower bone turnover be a cause of chest pain during childhood? Pediatric Cardiology 2010; 31:991-6. https://doi.org/10.1007/s00246-010-97434

PMid: 20552184

15. Feinstein RA, Daniel WA. Chronic chest pain in children and adolescent. Pediatric Annals 1986; 15: 685-9. https://doi.org/10.3928/0090-448119861001-07

PMid: 3785995

16. Kosic KC. Chest pain in paediatrics. Pediatric Clinics of North America 1999; 46:189-203.

https://doi.org/10.1016/S00313955(05)701 12-7
17. Cashman KD, Hill TR, Cotter AA et al. Low vitamin D status adversely affects bone health parameters in adolescents. American Journal of Clinical Nutrition 2008; 87:1039-44.

https://doi.org/10.1093/ajcn/87.4.1039

PMid: 18400729

18. Hocaoğlu FS- Emre, Sarıbal D, Oğuz O. Vitamin D Deficiency and Insufficiency According to the Current Criteria for Children: Vitamin D Status of Elementary School Children in Turkey. Journal of Clinical Research in Pediatric Endocrinology 2019; 11:181-8.

https://doi.org/10.4274/jcrpe.galenos.2018 .2018.0272

PMid: 30592191 PMCid: PMC6571535

19. Haimi M, Kremer R. Vitamin D deficiency/insufficiency from childhood to adulthood: Insights from a sunny country. World Journal of Clinical Pediatrics 2017; 6:1-9.

https://doi.org/10.5409/wjcp.v6.i1.1

PMid: 28224090 PMCid: PMC5296623 